\title{
Letrados da Amazônia Imperial e saberes das populações analfabetas durante a Revolução Cabana (1835-1840)
}

\author{
MAGDA RICCI \\ Universidade Federal do Pará, Belém, PA, Brasil \\ LUCIANO DEMETRIUS BARBOSA LIMA \\ Rede Estadual de Ensino do Pará, Belém, PA, Brasil
}

RESUMO

Neste artigo discute-se como alguns letrados e políticos da Amazônia compreenderam a cultura iletrada na Cabanagem, movimento ocorrido nessa região entre 1835 e 1840. Analisam-se relatórios de presidentes da província do Grão-Pará, estudos da época e centralmente a obra Motins politicos, do historiador e político imperial Domingos Antônio Raiol, o Barão de Guajará. Escrita entre as décadas de 1860 e 1890, a obra descreve as motivações para a guerra cabana pela ótica da ordem imperial, sobretudo após a ascensão do imperador D. Pedro II. Admite-se como hipótese que as mudanças educacionais e sociais, nascidas após os anos de 1870, embora tenham fomentado a criação de novas instituições escolares e ampliado o grau e a abrangência da instrução formal, elas também trouxeram temores na sua condução por se tratar de um local tão revolucionário quanto o Pará. Conclui-se que discutir os saberes cabanos - ainda que pela leitura arrevesada de Raiol - é criticar um tipo de educação formal, compreendendo o quanto ela pode desqualificar conhecimentos e saberes informais de mundo.

PALAVRAS-CHAVE

analfabetismo; Cabanagem; Amazônia; século XIX. 


\section{INTELLECTUALS OF THE IMPERIAL AMAZON AND WISDOM OF ILLITERATE POPULATIONS DURING THE CABANA REVOLUTION (1835-1840)}

\section{ABSTRACT}

This article discusses how some academics and politicians in Brazilian Amazonia understood the illiterate culture movements like Cabanagem in the region between 1835 and 1840. It reports the presidents of Pará province, time studies and political work are examined and in the center, the work Motins politicos, written by historian and political imperial Domingos Antônio Raiol, Guajará Baron. Written between 1860 and 1890, the book describes the motivations for the cabanos war from the perspective of imperial order, especially after the rise of Emperor Dom Pedro II. It is recognized as a hypothesis that educational and social changes, born after the 1870s, although they have encouraged the creation of new educational institutions and expanded the degree and extent of formal education, they also brought fears about the way driving, since it is such a revolutionary place like Pará conclude that discuss cabanos knowledge - although the tortuous Raiol reading - is criticizing a formal education, including how much can disqualify the knowledge and understanding of the informal world.

\section{KEYWORDS}

illiteracy; Cabanagem; Amazon; nineteenth century.

\section{INTELECTUALES EN LA AMAZONIA IMPERIAL Y LA SABIDURIA DEL POBLACIONES ANALFABETAS DURANTE LA REVOLUCIÓN CABANA (1835-1840)}

\section{RESUMEN}

En este artículo se discute cómo algunos académicos y políticos en Amazon Brasileña entendieron la cultura analfabeta en movimientos como la Cabanagem en la región entre 1835 y 1840. En él se examinan los informes de los presidentes de Pará provincia, estudios de tiempo y el trabajo político y en el centro, la obra Motins políticos, escrita por el historiador y político imperial Domingos Antônio Raiol, Guajará Baron. Escrito entre los años 1860 y 1890, la obra describe las motivaciones para la guerra cabana desde la perspectiva del orden imperial, sobre todo después de la subida del emperador Don Pedro II. Se reconoce como hipótesis que los cambios educativos y sociales, nacidos después de la década de 1870, a pesar de que han fomentado la creación de nuevas instituciones educativas y ampliado el grado y el alcance de la educación formal, también trajeron temores sobre su forma de conducir, ya que es un lugar tan revolucionario como el Pará concluir que discutir cabanos conocimiento -aunque el Raiol lectura tortuosa- es criticar a un tipo de educación formal, incluyendo cuánto puede descalificar el conocimiento y el conocimiento del mundo informal.

PALABRAS CLAVE

el analfabetismo; Cabanagem; Amazon; siglo XIX. 
$\mathrm{Na}$ segunda metade do século XIX, quando a história objetivava, entre outros aspectos, justificar os ideais de progresso e da ciência, os quais para muitos só seriam alcançados por meio da universalização da educação formal, um político e historiador paraense chamado Domingos Antônio Raiol, ${ }^{1}$ possuidor do título nobiliárquico de Barão de Guajará, elaborava os cinco volumes de seu mais conhecido estudo: Motins políticos ou história dos principais acontecimentos políticos na provincia do Pará desde o ano de 1821 até 1835. Originalmente publicada entre 1865 e 1890, a obra tem como foco os conflitos ocorridos no Pará durante o contexto posterior à independência política do Brasil até o final do período conhecido como Regencial e que, à época, conhecia-se como tempo da menoridade do imperador brasileiro Pedro II. Esse estudo foi produzido em uma conjuntura de envolvimento do autor nos debates relacionados às preocupações governamentais com os rumos da instrução pública brasileira. ${ }^{2}$ Também, em diversas circunstâncias, apresenta reflexões sobre a pressuposta ausência de um ensino formal destinado às classes populares do antigo estado do Grão-Pará - hoje chamado Amazônia - durante a primeira metade do século XIX. Essa ausência é ressaltada na participação dos grupos sociais não

1 Domingos Antônio Raiol foi um dos mais proeminentes intelectuais políticos do Norte do Brasil no século XIX. Nascido em Vigia, no Grão-Pará (30/3/1830), estudou no Liceu Paraense e formou-se bacharel em ciências jurídicas e sociais em 1854 pela Faculdade de Direito de Olinda. No início da década de 1860, entrou no meio político, sendo eleito por várias vezes deputado pela Assembleia Provincial e deputado pela Assembleia Geral, quando apoiou o projeto de Abertura da Amazônia ao Livre Comércio Internacional. Além disso, por indicação imperial, foi presidente das províncias de Alagoas (1882), Ceará (1882) e São Paulo (1883). No mesmo ano, foi agraciado com o título nobiliárquico de Barão de Guajará. Com a ascensão da República, abandonou o cenário político, falecendo na capital do Pará em 1912.

2 Elaborados durante o aprofundamento dos debates sobre a instrução pública no Segundo Reinado, o $1^{\circ}$ e o $2^{\circ}$ volumes de Motins politicos, publicados entre 1865 e 1868, incorporam de maneira indireta a inserção de Raiol na vida político-partidária. $\mathrm{O} 3^{\circ}, 4^{\circ}$ e $5^{\circ}$ tomos desse estudo, editados respectivamente em 1883, 1884 e 1890, logo após a aprovação da Lei Saraiva (1881), transpareceram de maneira evidente a relação desse intelectual com as questões educacionais nacionais, ao serem produzidos no momento em que Raiol assumiu o "cargo de delegado interino do inspetor geral da instrucção primaria e secundaria da corte" (O Liberal do Pará, 15/7/1879, anno XI, n. 158, p. 1) e, em seguida, a função de "provedor do collegio de N. S. do Amparo em Belém" ( $O$ Liberal do Pará, 13/5/1882, anno XIV, n. 105, p. 1). A partir de 1882, quando exerceu a função de presidente em algumas províncias do Império, o barão também expôs seu conhecimento de diversas questões do ensino público no Brasil. Em São Paulo, refletiu abertamente sobre a "Lei n. 130, de 25 de abril de 1880, que autorisou a abertura da Escola Normal" (Falla dirigida á Assembléa Legislativa Provincial de S. Paulo na abertura da $1^{a}$ sessão da $25^{a}$ legislatura em 16 de janeiro de 1884 pelo presidente, Barão de Guajará. São Paulo: Typ. da Gazeta Liberal, 1884, p. 9); e no Ceará, expressou desapontamento com os rumos tomados pela instrução pública nacional, ao afirmar que ela "nunca esteve como agora tão emaranhada em reformas e autorisações, algumas das quaes são inexequíveis" (Relatorio com que o Exm. Sr. Barão de Guajará passou a administração da Provincia do Ceará ao respectivo $2^{\circ}$ vice-presidente Exm. Sr. Commendador Antonio Theodorico da Costa no dia 17 de maio de 1883. Fortaleza: Typ. do Cearense, 1883, p.1). 
letrados nas lutas sociopolíticas deflagradas na região, conhecidas posteriormente como Cabanagem (1835-1840). ${ }^{3}$

A reconstrução analítica dessa conexão entre ausência de instrução e a participação política na Cabanagem, ressaltada nas páginas de Motins políticos, torna-se significante por dois aspectos principais que se constituem nos objetivos deste artigo. Primeiramente pela possibilidade de investigar o assunto pela ótica de um representante das elites brasileiras no Segundo Reinado, que considerava as populações analfabetas ou semiletradas no processo de lutas deflagradas na Amazônia na década de 1830 usando termos pejorativos como "parvos", "néscios" (Raiol, 1970, p. 565) e "turbulentos" (idem, p. 805), posicionamento que influenciou na desqualificação histórica desses grupos. Em segundo, por permitir verificar como o estudo de Raiol contribuiu para favorecer a construção de percepções depreciativas sobre os cabanos no Pará e para a criação do mito - o qual infelizmente perdura até nossos dias - de que não há populações significativas no Pará e na Amazônia e de que esse território seria um vazio humano. Dito isso, este artigo objetiva finalmente investigar as concepções do autor direcionadas à interação entre educação formal e participação no processo de lutas político-sociais deflagradas no Pará entre 1835 e 1840.

Conceitualmente, a presença de desníveis educacionais no interior de movimentos como a Cabanagem se constitui em um tema metodologicamente instigante para ser averiguado dentro de uma perspectiva de análise de caso. Como salienta Ginzburg (2006), as novas temáticas de história possibilitam adentrar-mesmo que parcialmente - "nas ideias, crenças, visões de mundo" de seus agentes mais próximos (idem, p. 12). Elas também permitem que direcionemos nossa análise ao "conjunto de atitudes [...] códigos de comportamento, próprios das classes subalternas" (idem, ibidem), as quais, naquele contexto, eram observadas em suas ações como distantes dos padrões considerados civilizados pela elite letrada local. ${ }^{4} \mathrm{E}$ ainda importante

3 A Cabanagem (1835-1840) constituiu-se em um movimento político e social deflagrado na província do Grão-Pará, com forte participação de caboclos, negros e índios, que ameaçou a manutenção do poder imposto pelo governo regencial sobre a região. Para mais informações, ver os estudos clássicos de: Chiavenato (1984), Cruz (1942), Di Paolo (1990), Hurley (1936) e Roque (1984). Já existem, contudo, importantes balanços analíticos desses estudos cabanos. Com focos diferentes, o balanço mais recente foi feito por Mark Harris. Nele, considera-se, de forma muito apropriada, os estudos produzidos por brasilianistas, além de se fornecer dados precisos para um rol muito significativo de autores e obras editadas no Brasil sobre o tema. Já balanços como o elaborado por Pinheiro também têm mérito especial por recuperar autores do estado do Amazonas, autores estes muitas vezes desconhecidos de um público mais amplo. Também publiquei um balanço das obras sobre os cabanos. Há de se notar ainda o levantamento bibliográfico elaborado por Vicente Salles. Intitulado Memória bibliográfica do Grão-Pará: Cabanagem, o levantamento de Salles arrola, em suas quarenta páginas, duzentas e duas obras entre livros, capítulos de livros, artigos em revistas e jornais. Salles ainda comenta várias dessas obras e oferece, sem dúvida, o mais completo arrolamento bibliográfico sobre o assunto. Consultar Harris (2010, p. 10-30); Pinheiro (2001); Ricci (2001, p. 241-274) e Salles (2005).

4 Na concepção de Norbert Elias, o termo "civilização" passou a ser gradativamente empregado pelos nobres, letrados e burgueses europeus a partir de finais do século XVIII, para assinalar uma série de costumes, comportamentos e condições de uma sociedade 
ressaltar que, embora a obra Motins politicos se tenha constituído em fonte para distintos estudos, este artigo irá percorrer um caminho que os trabalhos anteriores "haviam ocultado, deixado de lado ou simplesmente ignorado" (idem, p. 11), possibilitando adentrar em uma investigação que procura ir além da descrição de eventos político-sociais.

Além disso, mesmo que este artigo realize uma reflexão pontual, com base em uma obra específica, é relevante nos determos um pouco sobre a chamada ausência da "educação formal", ou melhor, os problemas dela no Pará e no Brasil durante o contexto da menoridade, sobretudo pelo imenso número de povos indígenas e pelo pouco e desprezível número de escravos de origem africana presentes na região amazônica no período analisado.

Como ressaltou o estudo de Bezerra Neto $(1998$, p. 186) sobre a criação de um asilo em Belém:

As palavras dos representantes do Estado tiveram [nos anos de 1870 no Pará] um sentido claro: o progresso ("prosperidade real") de um país tem por base a educação [...]. Chamo a atenção para a necessidade de educar os setores populares da sociedade visando a transformação do cidadão em "bons pais", "bons amigos" e "bons patriotas".

Assim, é importante ressaltar que na segunda metade do século XIX a preocupação com a instrução pública já ganhava as ruas, a política paraense e a nacional, mas que essa "necessidade de educar os setores populares da sociedade" vai se transformar em mote, sobretudo, depois dos anos de 1870, com a intensificação do processo abolicionista e com o fim da Guerra do Paraguai. No caso da Amazônia, iniciava-se uma época de prosperidade com o crescimento da produção do látex. Contudo, décadas antes, na primeira metade do século XIX, a escola ainda não se havia consolidado como principal espaço de instrução no Brasil. Na Amazônia, os problemas eram ainda maiores.

Na primeira metade do século XIX, a instrução formal coexistia com outros ambientes onde também se realizavam, sob as mais diferentes formas, práticas educacionais de caráter informal, particularmente nos recintos domésticos e religiosos. Não obstante, a existência de lugares onde o ensino era ministrado sem o controle das autoridades correspondeu, durante a monarquia, "a uma face não visível do icebergue educativo" (Canário, 2000, p. 79), transformando-se, no Segundo Reinado, em uma preocupação constante dos representantes do Estado, das "elites econômicas e intelectuais, frente à necessidade de controle social e da prevenção contra a 'desordem"' (Costa, 2007, p. 12).

como um todo. Tempos depois, serviu para distinguir ou comparar povos e nações como "civilizados" ou "bárbaros" e para expressar as distintas configurações de desenvolvimento científico ou artístico dos povos. No Brasil, o termo "civilização", adaptado da realidade escravista, foi largamente utilizado no século XIX, quando as elites vislumbravam na França ou Inglaterra os principais "modelos" de "civilização" a serem imitados. Ver Chalhoub (1996) e Elias (1994). 
O temor das elites imperiais diante da possibilidade de "subversão da ordem" influenciou diretamente nas políticas de ensino estabelecidas no Brasil durante o Segundo Reinado. Naquela conjuntura, muito mais que a simples difusão do conhecimento formal, havia um perceptível objetivo de "produção de um dispositivo de inclusão de todos na civilização" (Veiga, 2002, p. 7), responsável pela possibilidade de fixar "as relações de saber na sociedade, particularmente entre as populações pobres, fazendo desencadear todo um movimento de contenção dos seus saberes" (idem, ibidem), que se manifestou nas várias instâncias de poder.

Assim, ao mesmo tempo em que exerciam seu controle sobre o Estado e as atividades intelectuais, as elites imperiais também intensificaram o domínio sobre a instrução pública, pois, na percepção desses grupos, o ensino funcionava não apenas como maneira de "alcance do 'progresso'e da 'civilização' - mas também, e fundamentalmente, como elemento de direção das 'ideias do povo', de modo a reproduzir hierarquias e conservar a ordem imperial” (Schueler, 1999, p. 5), facilitando a "poupança com os gastos de hospitais, asilos e cadeias"(idem, p. 7). Desse modo, ao "atribuir significados idênticos às expressões 'classes pobres'/ 'classes ignorantes' / 'classes perigosas" (idem, ibidem), os representantes da ordem dominante na monarquia formalizaram a "ideia de que educar significava prevenir a criminalidade e as 'desordens sociais"” (idem, p. 8).

A memória dos tempos regenciais e da insubordinação das classes populares em todo o Império agia como um estimulante para as mudanças pensadas na instrução pública durante o Segundo Reinado. Não por acaso, essa conjuntura foi marcada por "iniciativas do Império para organizar a educação na Corte e nas Províncias" (Frade, 2010, p. 264).

Ainda cedo, uma das grandes transformações ocorridas no Império foi a efetivação do ato adicional de 12 de agosto de 1834, que, entre várias atribuições, possibilitou às províncias a "liberdade de legislar sobre o ensino primário e secundário, além de possibilitar que as Assembleias Legislativas Provinciais criassem e organizassem as instituições que dariam formação aos seus professores" (Schneider; Neto; Alvarenga, 2012, p. 179). Essas mudanças e discussões, que trouxeram à tona o tema da obrigatoriedade do ensino público, acabaram entrando em choque com outras instâncias educativas não oficiais, a exemplo das famílias, que compreendiam a instrução obrigatória como uma "ofensa ao pátrio poder, ao conjunto de direitos e responsabilidades que a família possuía sobre seus filhos, entre eles, de decidir se a prole seria, ou não, escolarizada" (idem, p. 180). Também a Igreja trazia o ensino para sua responsabilidade, sobretudo o ensino religioso.

Mesmo com todas essas especificidades, não há como deixar de considerar, no Império, durante o Primeiro Reinado e no período da menoridade, a existência das escolas, currículos, alunos e de um conjunto de regras, a maioria das quais, encaminhadas e avaliadas localmente. Nesse sentido menos amplo, liberalizado e trabalhado localmente (nas províncias), é que utilizaremos o conceito de educação formal. Não obstante, reconhecendo a escassez de estudos específicos relacionados às condições do ensino formal no Pará, durante o Primeiro Reinado e na Regência, fica evidente que ele teve seríssimos entraves na região até 1840 , com os distúrbios causados pela Cabanagem. A reconstrução da província foi difícil e demorada, e 
a população local só voltou aos patamares dos anos de $1820 \mathrm{em} \mathrm{1860.} \mathrm{Assim,} \mathrm{as}$ mudanças propostas na segunda metade do século XIX no Pará eram ainda mais urgentes que no restante do Brasil. A memória da "insubordinação" ou das lutas populares cabanas aumentava a necessidade de mais instrução pública. Daí a relevância da análise da obra de Raiol e do tema central deste artigo.

\section{UMA PROVÍNCIA DE ILETRADOS: A PRECARIEDADE DO ENSINO FORMAL NO GRÃO-PARÁ ENTRE O PRIMEIRO REINADO E A REGÊNCIA}

Durante grande parte do contexto colonial brasileiro, a "educação predominante no Brasil foi promovida por jesuítas” (Castanho, 2004, p. 37), sendo restrita a uma pequena parcela da população. As mudanças impostas pelo mundo ilustrado pombalino no Brasil (Maciel; Neto, 2006; Cruz, 1971) e na Amazônia (Coelho, 2003, 2006) bem como, posteriormente, os debates dentro do processo de ruptura política com Portugal, deflagrado em 1822, não representaram transformações revolucionárias na ampliação ou universalização do letramento no processo de educação nacional. As letras e mesmo a alfabetização no nascente Brasil Imperial e no Pará, em particular, continuaram representando uma prerrogativa para poucos privilegiados.

Mesmo com a perspectiva do imperador D. Pedro I de incentivar a criação de uma Comissão de Instrução Pública e da inserção, na Constituição de 1824, em seu artigo 179, da alínea 32, que garantiu a "gratuidade da instrução primária para todos os cidadãos" (Paiva, 1973, p. 61), grande parte dos jovens e crianças não tinha acesso ao conhecimento formal, seja pelo reduzido número de escolas, pelas precárias condições econômicas e sociais, ou pela predominância de "professores, praticamente sem nenhuma preparação mais específica para o magistério"(Castanho, 2004, p. 42). Essa situação, responsável por transformar os filhos das elites em integrantes de uma espécie de "ilha de letrados num mar de analfabetos" (Carvalho, 2007, p. 65), não se restringia a esta ou àquela região, mas abarcava praticamente todo o jovem Império, de acordo com José Murilo de Carvalho, existindo "um verdadeiro abismo entre essa elite e o grosso da população em termos educacionais" (idem, p. 79). Assim, mesmo com a existência de projetos que criaram cursos superiores (como a Carta de Lei do Imperador D. Pedro I, de 11 de agosto de 1827, que dava origem, ao mesmo tempo, a dois cursos de ciências jurídicas e sociais, em Olinda e São Paulo, e de outras propostas, que visavam à criação de Escolas de Primeiras Letras em diversos pontos do nascente Império), o sistema educacional brasileiro, nas primeiras décadas do século XIX, apresentava-se caracterizado pelo abandono e ausência de políticas públicas mais eficazes.

Já no contexto da Regência, foi estabelecido o ato adicional de 1834, responsável por incumbir às "províncias o direito de regulamentar e promover a educação primária e secundária” (Romanelli, 2006, p. 40). Contudo, na prática, o que sucedeu foi a "tentativa de reunir antigas Aulas Régias em liceus sem muita organização" (idem, ibidem), pois o ensino, principalmente o "secundário", "acabou ficando nas mãos da iniciativa privada e o ensino primário foi relegado ao abandono, com 
pouquíssimas escolas, sobrevivendo à custa do sacrifício de alguns mestres-escolas" (idem, ibidem). Durante o período da Regência, na Província do Pará, o quadro de precariedade do ensino formal em geral era tão significativo que os próprios presidentes expressavam certo desalento com a situação da educação, como pode ser observado no trecho exposto a seguir:

A instrucção publica, Senhores, [...] pouco ou talvez nenhum incremento tem tido [...] e instante em promovel-a pela firme conviçção de sua utilidade [...] e quando eu esperava hum passo em vantagem da instrucção, foi que infelizmente conheci, que não havia quem me segundasse em tão importante empreza. (D'Oliveira, 1833, p. 2-3)

O respectivo fragmento, retirado de um relatório do presidente provincial Machado de Oliveira em 1833, às vésperas da deflagração da Cabanagem, possibilita averiguar a complexa condição na qual se encontrava o ensino da região naquele contexto. Essa mesma autoridade, na tentativa de amenizar a situação da educação no Pará e suprir a ausência de professores, dispensou o "exame e concurso das cadeiras de primeiras Letras daquellas Villas e Povoações mais remotas da Capital" (idem, p. 2), obtida com autorização do Governo Regencial. Contudo, em razão da ausência de postulantes aos cargos e do posterior abandono de algumas cadeiras "pelos professores, sem outro algum motivo mais do que a falta de perseverança em objecto de tão vital interesse" (idem, p. 3).

No decorrer da Cabanagem, a situação da instrução pública no Pará agravou-se a ponto de o presidente provincial Soares Andréa expressar em relação a esse tema que se "poderia ao menos estabelecer-se nesta Capital huma Escolla Normal, aonde se apurassem mais os individuos que se destinassem a ser Professores das primeiras Letras, ou das Aulas maiores"(Andréa, 1838, p. 34), pois se "tem conservado o abuso de entender-se que bastão para mestres de primeiras letras homens que mal sabem ler, e de modo nenhum escrever certo, e ainda menos contar" (idem, ibidem). Ainda de acordo com Andréa, é "por isto que lhe tem sido arbritados ordenados tão pequenos, que só acceitão as cadeiras alguns desgraçados [...] que nenhuma tenção tem de se empregarem seriamente em tal trabalho" (idem, ibidem). Essas críticas eram possivelmente uma reação à aprovação da lei provincial n. 6, de 8 de maio de 1838 , que "authorisou o provimento das cadeiras vagas em pessoas hábeis, podendo entretanto, na falta destas, nomear-se quem as regesse com vencimento de metade dos respectivos ordenados" (Benjamin, 1854, p. 38).

Em agosto de 1839, quando a Cabanagem encontrava-se em seus momentos finais, o presidente Bernardo de Souza Franco expressou, em um discurso dirigido à Assembleia Legislativa Provincial, que "he lastimavel [...] o estado a que está reduzida a instrucção publica da Provincia. Há em toda ella uma aula de Philosophia Racional, e Moral, uma de Rethorica, e huma de Lingoa Francesa" (Souza Franco, 1839, p. 4). Para essa autoridade, a luta contra os cabanos representava o choque entre "ignorância" e "civilidade". Segundo ele, os melhoramentos na educação "suppoem um estado de socego e tranquilidade [...] de obstar de todo modo possível á nova irrupção da força bruta, e desenfreada contra a massa inteligente, illustrada e pacifica [...] do desrespeito dos inferiores para com os Superiores" (idem, p. 5). 
No ano de 1840, quando os últimos grupos cabanos eram reprimidos no interior do Pará e as condições educacionais da província ainda se encontravam calamitosas, o presidente João Antônio de Miranda estabeleceu em um de seus discursos uma conexão entre o processo de lutas na região e a instrução pública ao afirmar que a educação é "filha da paz publica e da tranquilidade dos espíritos, e não era possível, que no estado vertiginozo, que por algum tempo desgraçou a Provincia, [...] restituir-lhe esse descanço, que produz as sciencias, e as fortunas" (Miranda, 1840 , p. 20). Esse fragmento permite a observação de dois aspectos relevantes. $\mathrm{O}$ primeiro repete, em grande parte, as falas presidenciais anteriores, ao denunciar as problemáticas condições do ensino na província. O segundo argumento, ao conectar diretamente a precariedade da instrução pública no Pará ao processo de lutas na região, torna-se um indício importante para a compreensão de como algumas autoridades realizavam essa interação na primeira metade do século XIX.

Praticamente na mesma conjuntura, a situação da educação na Amazônia também foi analisada por alguns intelectuais pelos mais variados pontos de vista. Em sua Corografia paraense, Ignacio Accioli de Cerqueira e Silva expressou que, no início do século XIX, a instrução na capital do Grão-Pará "se acha no estado de atrasamento" (Silva, 1833, p. 152), possuindo apenas "duas aulas publicas nos dous bairros da Capital, uma de filosofia racional e moral, e outra de rethorica, não fallando do seminário Episcopal onde se ensinão essas artes e theologia dogmatica; duas cadeiras de primeiras letras e quatorze em diversas Villas" (idem, ibidem). Ainda de acordo com esse estudioso, existia "igualmente na Capital uma aula de geometria e dezenho para os militares, alem d'algumas escolas particulares na mesma Capital e Villas cujos Paroclos e particulares se entregão ao magistério" (idem, ibidem).

Antonio Ladislau Monteiro Baena, em sua obra Ensaio corográfico sobre a provincia do Grão-Pará, publicada originalmente em 1839, expressou que o estabelecimento da "Instrução Pública, base da moral e da civilização, tem somente dois graus distintos" (Baena, 2004, p. 203) e não se encontrava em bom estado na capital da província, existindo em Belém, no campo das primeiras letras, "seis na cidade [...] quatro sem professor" (idem, p. 204); e, no interior, muitas localidades, "tudo sem professor" (idem, ibidem). Em seguida, Baena expõe um esboço geral da educação provincial, argumentando que:

Apresentando pois o precedente quadro do sistema de instrução e escolas públicas 24 vilas, 3 lugares, 4 freguesias, e 2 missões, que foram contempladas na distribuição do ensino gratuito de ler e escrever; e indicando o mesmo quadro que das povoações compreendidas desta distribuição ainda estão sem mestre 14 vilas, 3 lugares, 3 freguesias e duas missões; e compondo-se a Província de 44 vilas, 61 lugares, 10 freguesias, e 7 missões, que atualmente estão desfalecidas de escolas de primeiras letras, e portanto aqueles povos acham-se privados dos princípios essenciais, de que depende a felicidade individual, e aos quais tem igual direito como indivíduos sujeitos a um mesmo governo. (idem, p. 207)

Ao descrever a oferta de ensino formal no Pará no início da década de 1830, Baena critica a ausência de professores e escolas, alertando que essa situação poderia ocasionar consequências negativas na política provincial, pois, segundo ele, "quantos 
males não podem afetar a causa pública exercitando empregos judiciais, e municipais homens analfabetos" (idem, p. 207-208), pois são "numerosos os fatos provenientes da ignorância dominante nas vilas [...] por deficiência das escolas do primeiro grau da instrução pública" (idem, p. 208). As percepções dessas autoridades e intelectuais, além de relevantes para a compreensão das condições educacionais do Pará, possuem em comum o posicionamento de denúncia do quadro de precariedade do ensino no contexto regencial. Assim, considerando que o "problema da instrução está sempre ligado ao da revolução" (Manacorda, 2006, p. 287), o próximo tópico irá expor o pensamento de um intelectual e político paraense sobre a participação dos grupos sociais "analfabetos" ou "subletrados" nos "jogos de poder" da Amazônia.

\section{CHEGANDO AOS “MOTINS DA IGNORÂNCIA": INTERAÇÃO ENTRE LUTAS POLÍTICO-SOCIAIS E EDUCAÇÃO FORMAL NOS ESCRITOS DO BARÃO DE GUAJARÁ}

Nas páginas anteriores, observou-se que a existência de um grande número de iletrados no Pará, durante as primeiras décadas do século XIX, constituiu-se em tema de reflexão, para que algumas autoridades e estudiosos, sob os mais distintos enfoques, externassem preocupações quanto às dificuldades da província em alcançar as "benesses" da instrução. Décadas depois, já durante o Segundo Reinado, a narrativa de Motins políticos aprofundou essa discussão, expondo as condições educacionais da região durante o processo de lutas regenciais. Inicialmente, a obra apresenta um quadro sobre a estrutura escolar paraense, expressando que havia em Belém "apenas duas escolas de primeiras letras pelo sistema de ensino mútuo para o sexo masculino e uma para o feminino" (Raiol, 1970, p. 565-566). Além disso, "três outras do antigo ensino individual estavam sem mestres e sem esperanças de os ter! [...] Duas outras, de geometria e francês, que tinham sido criadas, permaneciam por muito tempo sem mestres e sem discípulos!" (idem, ibidem).

A existência de um número reduzido de escolas e professores se constituía em um dos problemas iniciais apresentados pelo barão que dificultavam o desenvolvimento educacional da província. Além disso, Raiol enfatiza, no respectivo fragmento, que, mesmo com a abertura de vagas para docentes, o número de pessoas habilitadas para preencher essa atividade era insuficiente na região. Segundo esse autor, a escassez de escolas e professores direcionados às mais diversas áreas de ensino, aliada à ineficiência de medidas governamentais, não consistia em dificuldade que atingia apenas as populações da capital Belém. No interior, o quadro apresentava-se mais desesperador, pois, nas povoações, a condição da instrução era "ainda pior e mil vêzes mais deplorável! Só na Vigia, em Cametá e em Santarém havia ensino de Gramática latina [...]. Nas outras localidades só havia escolas de instrução primária, e essas mesmas eram raras e pèssimamente dirigidas" (idem, p. 566).

A denúncia do barão em relação à situação da educação do Pará nas primeiras décadas do século XIX deixa transparecer que, tanto em Belém como no interior, predominava, às vésperas da Cabanagem, um quadro de abandono do ensino público, favorecido pela suposta inépcia das autoridades, que, segundo Raiol, pagavam 
honorários insignificantes. Ao lado da falta de apoio dos governantes, esse autor expressa que as escolas "eram pouco freqüentadas. O número dos estudantes que se tinham matriculado em tôdas as aulas da capital, [...] apenas havia atingido a trezentos e setenta e um em 1832, com pequenas alterações nos três anos posteriores!" (idem, ibidem).

As críticas de Raiol em relação ao suposto estado de abandono do ensino no Pará na primeira metade do século XIX destinavam-se, entre outros aspectos, à perspectiva de demonstrar que, além das disputas entre facções políticas, a precariedade das escolas, a ausência de professores e a falta de interesse dos alunos também eram problemas que poderiam contribuir para a deflagração de um movimento insurrecional, pois, em sua percepção, a "ignorância é uma verdadeira paralisia no espírito humano; entorpecendo a razão, ofusca a consciência [...] torna enfim a criatura vítima das paixões ruins e do primeiro aventureiro que melhor souber excitar-lhe o instinto embrutecido" (idem, p. 568). Por intermédio dessas palavras, o autor de Motins politicos deixava transparecer que, em seu pensamento, o estado desastroso do ensino na província não podia ser dissociado do processo de lutas que iria eclodir pouco tempo depois.

No texto de Motins políticos, a preponderância de características que denunciavam a precariedade no meio educacional paraense durante a conjuntura do Primeiro Reinado e Regência acabou servindo como argumento para a perspectiva de aproximação entre ineficiência educacional e levantes políticos no Pará. Assim, o barão formulou algumas interrogações, argumentado que em "tais circunstâncias, o que se podia esperar da população agitada que dominava a situação política da província? O que devia esperar-se de homens sem instrução, nem conhecimento dos mais comezinhos problemas sociais?" (idem, ibidem).

Além desses pontos, havia também na narrativa de Motins políticos a perspectiva de explicitar a situação de "analfabetismo" vivenciada por grande parte das populações rebeladas na Amazônia em um patamar distante dos ideais civilizatórios apreciados no período. Dessa forma, por meio de um vocabulário assinalado por opor "sua erudição de escrita à pobreza cabana" (Ricci, 1993, p. 22), a obra do barão comporta em seu texto um caráter "civilizatório, superior e rico, procurando derrotar seus adversários cabanos inclusive em sua linguagem" (idem, ibidem).

Ademais, a descrição dos diversos movimentos deflagrados no Pará entre as décadas de 1820 e 1830, a que se propôs o barão, também é marcada pela perspectiva de demonstração de capacidade intelectual, criticando continuamente a suposta condição de muitos integrantes das facções rebeldes não serem portadores de uma educação formal, considerada pelo autor como essencial para qualquer um que procurasse envolver-se nas questões políticas. Por conseguinte, é significativo o valor atribuído por Raiol à cultura letrada em sua obra. Com essa prerrogativa, esse autor qualificou a tomada de poder no Pará pelas chamadas "turbas", não apenas ameaçadora do caráter civilizacional e moral, mas também da ordem político-social:

A ignorância de um povo é sempre favorável às ambições dos parvos; é seiva que nutre e eleva os néscios. Os pregões dos estultos só não têm eco nos espíritos cultos e moralizados. E no Pará infelizmente a maioria da população era então quase indiferente ao influxo benéfico da instrução! (Raiol, 1970, p. 565) 
Além de facilitar a percepção da valorização que Raiol dava à educação formal, o respectivo trecho também deixa transparecer outros aspectos, como a denúncia do autor em relação ao estado do ensino no Pará durante a conjuntura do Primeiro Reinado e da Regência, agravada pela suposta demagogia de alguns líderes rebeldes que teoricamente tiravam proveito desse quadro de "ignorância" predominante na região. Sobre esse aspecto, é interessante destacar que o barão, além de tentar conceber a existência de uma maior "facilidade" das populações analfabetas serem "ludibriadas" e "cooptadas" por líderes rebeldes "astutos", também acreditava que a linguagem das elites letradas, em razão de uma suposta riqueza gramatical e discursiva, era pouco compreendida por esses grupos, que, segundo ele, não se sentiam atraídos por esses discursos, inacessíveis ao seu entendimento. Assim, era a existência de uma linguagem "simples" e "virulenta", praticada pelas lideranças rebeldes, oriundas das camadas populares e portadoras de características próprias, que conseguia, de fato, "iludir" as "turbas", fazendo com que essas populações ficassem envolvidas nos motins deflagrados na região:

A linguagem rústica do homem do povo quase sempre influi mais sobre as primeiras camadas da sociedade do que a linguagem meditada dos espíritos cultos. As massas populares se deixam faccilmente mover sob a influência das primeiras impressões, e os que falam a mesma linguagem. (idem, ibidem)

Por meio desse fragmento, é possível verificar que, no pensamento de Raiol, as lideranças populares dos motins no Pará são vistas como responsáveis por "incitar" as "turbas" na participação dos movimentos insurrecionais. Nesse processo, o "improviso" e o uso de palavras, supostamente mais "compreensíveis" ao entendimento e adequadas aos valores das classes populares, tornavam-se fundamentais, segundo Raiol, para o apoio aos ensejos desses líderes. Assim, na opinião do autor de Motins políticos, muito além dos anseios e projetos específicos de caboclos, negros e índios, participantes do processo de lutas, deflagradas na Amazônia, existia um quadro de "manipulação" dos grupos sublevados, os quais, analfabetos ou semiletrados, eram descritos com base em uma imagem estereotipada e negativa. Além disso, o livro de Raiol apresenta as populações pobres e escravas do Pará como supostamente "enganadas" por "ambiciosos" líderes rebeldes, que não mediam esforços nem escrúpulos para alcançarem seus objetivos. A partir desses pensamentos, o barão defende que a política deve constituir-se em monopólio das elites letradas, excluindo-se qualquer participação das classes populares que não possuem educação formal, principalmente por considerar que elas são facilmente iludidas:

Adulterando os fatos, desmoralizando a lei e os seus executores, excitando os ódios e os maus instintos populares, esses chamados órgãos da opinião pública deturparam o nobre apostolado da imprensa e causaram a ruína da província. Amortecido o sentimento de mútuo respeito entre os cidadãos, e predispostos os ânimos à turbulência pelos germens da anarquia inoculados na população, foi-lhes fácil completar a obra de dissolução moral, sublevando as classes ínfimas da sociedade contra as primeiras, mais graduadas e esclarecidas. (idem, p. 971) 
Para Raiol, um dos pontos que mais contribuíram para a deflagração do processo de lutas no Pará foi a ação de diversos pasquins que, portadores de uma linguagem rústica e radical, "insuflavam" as "turbas" a realizarem diversos atos de "violência" "desordem". Sobre esse aspecto, a narrativa de Motins politicos apresenta uma crítica direta aos eventuais erros de grafia contidos nos escritos de algumas lideranças dos revoltosos, como os presentes nos textos do "rebelde panfletário" Lavor Papagaio, que, segundo Raiol, os "poucos escritos seus que temos lido, [...] denotam, além de tudo, a mais crassa ignorância da língua portuguêsa: parece que lhe eram estranhos até os princípios mais elementares de gramática" (idem, p. 506).

Como é possível verificar nesse fragmento, o jornalista cearense Vicente Ferreira Lavor Papagaio, que redigia o pasquim denominado Sentinela Maranhense na Guarita do Pará, em oposição ao governo regencial, recebeu críticas na obra Motins políticos não apenas em razão de seus pensamentos contrários à autoridade regencial, mas também por sua suposta incapacidade intelectual para exercer a atividade na imprensa. Assim, fica perceptível que as censuras de Raiol direcionadas à ausência de educação formal entre os integrantes das chamadas "turbas" e a relação destas com os chamados motins não se destinavam unicamente às massas cabanas anônimas; elas dirigiam-se também a algumas de suas lideranças, acusadas de não possuírem quase nenhuma instrução formal e consideradas incapacitadas para assumir o poder.

Ainda se referindo a Lavor Papagaio, Raiol lamentava a situação, declarando sua surpresa com aquilo que, segundo ele, reafirmava o "estado de abatimento moral em que se achava a sociedade paraense para deixar-se arrastar por um aventureiro sem instrução nem sequer da língua em que escrevia! Era a triste época em que na província se reputava sábio quem mal falava o latim!" (idem, p. 565). Além dessas críticas, em diversos momentos da narrativa de Motins políticos, Raiol utiliza-se do argumento da falta de educação formal de grande parte dos grupos rebelados para desprestigiar e recriminar a organização do movimento em geral, ironizando, por exemplo, a nomeação, por parte dos cabanos, de pessoas analfabetas para determinadas funções políticas no governo, como pode ser observado na citação a seguir:

Tudo era burlesco! Em certos lugares havia até embaixadores e ajudantes de embaixador! Denominavam assim os encarregados de avisar e aliciar gente pelos sítios e povoados. Eram quase todos analfabetos; mal sabiam escrever os que se presumiam mais instruídos. (idem, p. 929)

Um olhar mais detido nesse trecho da obra Motins politicos permite compreender que, além de criticar a participação de populações analfabetas nas lutas político-sociais do Pará, Raiol também se utiliza da ironia para se referir à organização administrativa dos cabanos. Nesse sentido, o uso da palavra "burlesco", para definir o controle rebelde sobre a província, sugere que a participação das classes populares no poder deveria ser ridicularizada, seja pela sua suposta incapacidade no controle da região ou por simbolizar uma perspectiva de "desordem" e ausência de valores considerados civilizados.

Após recriminar, em diversos momentos, o envolvimento de populações analfabetas no processo de lutas no Pará, Domingos Antônio Raiol, na parte final 
de sua obra, argumenta a favor da difusão de um ensino técnico entre as populações amazônicas no final do século XIX, como forma de controlar o suposto potencial "ameaçador" que elas representavam. E realiza, no último tomo de Motins políticos, uma espécie de manifesto em favor do desenvolvimento da instrução pública na região ao expressar:

Eleve-se a instrução popular à altura de um verdadeiro sacerdócio derramando-a com prodigalidade por entre as multidões; liberalize-se a tôdas as classes a educação profissional de que carecem; substitua-se a ignorância pelo conhecimento do bem coletivo e individual; moralize-se e afeiçoe-se o povo ao trabalho; ilustre-se em suma a opinião pública, e todos abominarão as doutrinas subversivas como fontes perniciosas da anarquia. (idem, p. 1.006)

Além de reveladora acerca das percepções do barão em relação às supostas "ameaças" à ordem político-social que as massas populares não letradas representavam, essa citação torna-se interessante em razão de expor o pensamento desse autor, no sentido de aproximar aspectos como "analfabetismo" " "anarquia". Fazendo uma "ponte" entre passado e presente, ao referir-se às "desordens" ocorridas na primeira metade do século XIX no Pará, Raiol aponta para a necessidade de incentivo por parte das autoridades regionais e nacionais do Segundo Reinado à difusão de um ensino técnico entre as populações pobres como forma de controlar as classes populares e prevenir futuros movimentos insurrecionais. Desse modo, havia por trás de um suposto incentivo ao desenvolvimento da educação pública da província um jogo de interesses centrado na perspectiva de controle político-social sobre as "turbas", pois a expansão do ensino simbolizava, na visão do autor, a melhor maneira não apenas de as elites letradas consolidarem o domínio, mas também a solução para impor costumes "civilizados" à população. Ao final de sua narrativa, Raiol descreve aquilo que entendia como "comportamentos"e "vícios" dos variados grupos sociais e étnicos envolvidos na Cabanagem. Esses "maus comportamentos" eram geralmente aproximados da ausência de educação formal:

Não contestamos que a anarquia no Pará fosse o resultado fatal das lutas entre facções, e nem destas era lícito esperar outra coisa, formadas como eram de gentes desconhecidas e sómente capazes sequela ${ }^{5}$ aos turbulentos e ambiciosos sem moralidade, sobressaindo nos últimos tempos os malfeitores afamados, os vadios e analfabetos que sobre serem de costumes dissolutos, viviam na mais crassa ignorância, sem a menor noção dos deveres sociais. (idem, p. 973)

Para o barão, as ações políticas realizadas pelas populações não letradas eram quase sempre associadas a um perfil negativo, distante dos ideais considerados "civilizados", por sua vez moldados nos valores europeus. Assim, em diversos

5 Sequela aqui significa "grupo de pessoas que seguem o interesse de alguém”. (Houaiss, A.; Villar, M. S. Dicionário Houaiss da lingua portuguesa. Rio de Janeiro: Objetiva, 2009). 
momentos da narrativa de Motins políticos, as populações analfabetas eram ligadas à "barbárie" e à "violência". Nessa perspectiva, Raiol argumenta que, durante a Regência, "infelizmente a maioria da população era então quase indiferente ao influxo benéfico da instrução!" (idem, p. 565). Para esse autor, os comportamentos considerados "perigosos" das classes populares no Pará só poderiam ser contidos por meio de um grande projeto educacional que fixasse o aprendizado e, consequentemente, a "civilidade" na região, pois, somente disciplinando as "turbas", nos "valores" pedagógicos considerados "adequados", seria possível evitar que motins como os deflagrados durante a primeira metade do século XIX voltassem a ocorrer.

Segundo Raiol, era tarefa fundamental das autoridades inserir nas mentes das classes populares uma "disciplina, que só pode ser uma aprendizagem socializada pela escola" (Revel, 2009, p. 179), na qual os ideais de "civilidade" funcionariam como um dispositivo didático de controle, voltado para a incorporação das "turbas", aos anseios considerados seguros pelos grupos dominantes no Brasil da segunda metade do século XIX. Assim, no pensamento do barão, somente a concretização de ações educacionais mais efetivas por parte das autoridades do Império funcionaria como medida de controle e obediência das "turbas", que, se permanecessem analfabetas, poderiam representar uma ameaça constante ao status quo.

Dessa forma, a narrativa de Motins políticos não possuía apenas o objetivo de reconstruir uma parte da história do Pará no contexto do Primeiro Reinado e da Regência. Ela estava inserida em um universo bem mais amplo, que implicava também, por meio do uso de um vocabulário erudito, a conscientização e alerta das autoridades políticas e dos demais membros das elites regionais e nacionais contemporâneos ao autor quanto ao "medo do potencial revolucionário da gente comum" (Thompson, 2002, p. 25). Esse aspecto é evidenciado, ao longo do livro, pela valorização da educação escolar, deixando transparecer a existência de um constante "desejo de dominar e de moldar o desenvolvimento intelectual e cultural do povo na direção de objetivos predeterminados e seguros" (idem, p. 31), na Amazônia, durante o Segundo Reinado.

\section{OS SABERES CABANOS NOS REVESES DA LEITURA DE RAIOL}

Ao longo do tópico anterior, foi possível verificar que a narrativa de Motins políticos vai muito além da exposição de insurreições, conflitos políticos e disputas pelo poder deflagrados na província do Pará durante o contexto histórico das décadas de 1820 e 1830. Ela também representa uma interessante fonte de reflexão sobre a oposição entre portadores de saberes formais e informais na Amazônia no transcorrer do século XIX. Nesse sentido, como já foi enfatizado nas páginas precedentes, subsiste, ao longo dos tomos desse livro, um complexo processo de choque entre conhecimentos - letrados e iletrados - que extrapolam, em alguns momentos, a própria perspectiva de história política proposta pelo autor, denunciando insistentemente a presença de outras questões, das quais a pena de Domingos Antônio Raiol não conseguiu, ou não almejou, se esquivar.

Desse modo, por mais que tenha enfatizado - em vários momentos de sua narrativa - uma atitude valorizadora da educação formal e, consequentemente, a 
suposta "inferioridade" dos saberes pertencentes aos grupos sociais não letrados, o barão deixa transparecer, pela observação de diversos fragmentos, situações responsáveis por contrariar essa perspectiva hegemônica. Assim, o uso de conhecimentos e artifícios diversificados por parte das populações rebeldes não alfabetizadas conseguiu suplantar, em determinadas situações, a própria lógica defendida pelo autor ao ratificar em momentos específicos condições vantajosas aos grupos cabanos durante o processo de lutas na Amazônia.

Em seus diversos volumes, o livro Motins políticos é caracterizado por passagens que evidenciam esses "saberes cabanos", contrariando as reflexões sobre a inferioridade intelectual das populações não letradas, obstinadamente ressaltadas por Raiol (1970). Dessa maneira, uma das características atribuídas aos rebeldes que mais corporificam essa condição consiste na perspectiva de expor o uso de forma vantajosa do conhecimento informal sobre os recursos oferecidos pelo meio natural amazônico, como pode ser verificado no fragmento exposto a seguir, referente às astúcias e espertezas dessas populações:

Batidos os rebeldes em um ponto com perdas mais ou menos consideráveis, êles fugiam, internavam-se pelos matos, e pouco depois apareciam fortificados noutros pontos repetindo os mesmos atentados. Conhecendo os sertões e os sítios, sabiam caminhar tão bem de dia como de noite. Era-lhes fácil viajar por terra ou pelos rios, e podiam com vantagem em qualquer tempo as estradas, os caminhos e desvios que melhor conviessem aos seus planos. (idem, p. 902)

As palavras do barão sobre os saberes que os cabanos possuíam do meio natural amazônico demonstram, antes de tudo, que o conhecimento sobre as florestas e rios, adquirido pela experiência, tomava uma importância significativa em tempos de guerra. Além disso, o fragmento também revela que, mesmo dentro de um quadro de inferioridade bélica, os grupos responsáveis pela oposição ao "governo legal" utilizavam-se de estratégias diversificadas, formuladas com base em suas vivências, objetivando desestabilizar ou, pelo menos, enfraquecer os representantes do poder regencial na Amazônia. O conhecimento do meio natural amazônico do qual as classes populares no Pará eram possuidoras foi essencial para o prolongamento do movimento cabano, ao favorecer a efetivação de diversos ataques, emboscadas e outras incursões, com relativa vantagem em relação às tropas regenciais, majoritariamente oriundas de outras províncias e geralmente desconhecedoras dos perigos de áreas de floresta e rios da região. $\mathrm{O}$ uso dos recursos naturais pelos grupos cabanos demonstra que essas populações, mesmo excluídas dos saberes formais, possuíam uma grande experiência sobre as maneiras de sobrevivência no meio das matas e dos igarapés da região. Um exemplo dessa situação pode ser verificado na emboscada realizada pelos rebeldes na região do Acará, responsável pela morte do coronel Marinho Falcão, em 1834:

A expedição no dia 25 tinha subido o Acará até o ponto chamado Guaiabal, em que o rio diminui muito de largura. Eram quatro horas da tarde. Um trôço de quarenta facciosos estava escondido no mato à margem direita, atrás de tron- 
cos de árvores seculares que ali as havia e se debruçavam sôbre as águas. Uma voz perguntou que fôrça era aquela, para onde ia e qual o seu fim. Ninguém respondeu. E após vários vivas que ecoaram na selva, seguiu-se uma descarga de mosquetaria. [...] A expedição repeliu êste ataque inesperado fazendo fogo renhido contra os agressores. Mas as balas e metralhas que despejou serviram apenas para cortar e desflorar os arvoredos. [...] O coronel Marinho Falcão tinha caído sôbre o tombadilho do navio, transpassado por uma bala. (idem, p. 523)

Apesar da percepção estereotipada e negativa feita por Raiol acerca dos grupos cabanos no fragmento, a descrição sobre a emboscada realizada no rio Acará se constitui em um significante documento sobre a utilização de saberes e estratégias por parte das populações analfabetas ou subletradas amazônicas, com a finalidade de sobrepujar as forças militares regenciais, geralmente superiores em armamento e treinamento.

Em contrapartida, no olhar do barão, as ações realizadas pelas populações não letradas eram quase sempre associadas a um perfil negativo, distante dos ideais civilizatórios, delineados com base nos valores europeus. Assim, muito além dos movimentos insurrecionais, a narrativa de Raiol apresenta de maneira implícita um choque constante entre essas duas formas de conhecimento, colocando a educação formal como superior, propiciadora do "progresso" e da "civilização", enquanto os saberes dos cabanos são reduzidos a uma conotação depreciativa.

Contudo, é também indubitável, ao longo dos volumes de Motins políticos, a presença de várias passagens caracterizadas por conter aspectos concernentes ao conhecimento de mundo dos cabanos, com descrições sobre os comportamentos, costumes e saberes dessas populações. Sobre esse aspecto, o fragmento exposto a seguir, referente a determinadas práticas e modos dos grupos rebeldes, ganha relevância em virtude da riqueza de detalhes:

Vestiam camisas e calças de diferentes panos, compradas e feitas à sua própria custa. Para regularizar êste variado uniforme, tingiam depois umas e outras na casca de muruxi fervida em água, dando a tôdas a côr avermelhada dêste arbusto. Raros eram os que usavam de calçados e chapéus. [...] Frutos agrestes, um pouco d'água com farinha serviam-lhes de refeição muitas vêzes. Desconhecendo os cômodos e gozos da civilização, eram fáceis de contentar; resignavam-se a tudo. (idem, p. 831-832)

A interessante descrição presente no último tomo de Motins políticos, referente às vestimentas e condutas das tropas cabanas que conquistaram Belém em 1835, possibilita já de imediato a constatação do caráter negativo direcionado aos saberes das populações não letradas, empregado na obra do barão. O conhecimento informal dos rebeldes, verificável na elaboração de suas roupas e alimentos, é prontamente menosprezado e transformado em "rusticidade" ou "ignorância" por Raiol, ao enfatizar que os cabanos desconheciam não apenas os saberes letrados, mas também os "cômodos gozos da civilização". O trecho também representa uma crítica à "participação política" das classes populares, que, descritas como "analfabetas" e 
"embrutecidas", eram vislumbradas como incapazes de assumir o poder de uma província. Essa argumentação simboliza uma perspectiva de legitimar a existência de uma hierarquia, não apenas política, mas também cultural, na qual as classes dominantes, portadoras de educação formal, deveriam legitimamente permanecer com o controle sobre a população não letrada, vista como inábil à condução de seu próprio destino.

Embora o texto de Raiol esteja repleto de fragmentos que atestam a presença de procedimentos e astúcias originárias dos saberes dos habitantes da Amazônia, esses artifícios das populações da floresta são colocados em um patamar inferior em relação às ações propiciadas por pessoas portadoras do conhecimento formal. Nesse processo, os diversos grupos étnicos e sociais participantes dos "motins" são vistos como uma "massa turbulenta", composta por vadios e bandidos, de quem o analfabetismo é vislumbrado como um agravante, responsável pela deflagração de muitos casos de destruição e desordens na capital e interior do Pará.

A despeito de apresentar essas prerrogativas, a narrativa de Motins politicos se notabiliza pela riqueza de detalhes com que expõe o modo de vida e, consequentemente, os saberes das populações não letradas no Pará durante a Regência. Um dos fragmentos reveladores, em razão da diversidade de minúcias relacionadas ao uso dos saberes pertencentes às populações não letradas, corresponde à descrição da habitação que serviu como esconderijo do líder cabano Eduardo Angelim, construída com auxílio de índios durante os momentos finais do processo de lutas:

Eduardo Angelim estava efetivamente à margem de um lago nos confins do Acará, no chamado Rio Pequeno. Habitava em uma humilde palhoça que construíra com auxílio dos gentios aldeados naquelas longínquas regiões. [...] A casa era coberta de ramas de palmeiras que também serviam de tapagem aos compartimentos. Os bancos de assento eram pedaços madeiros broncos, e os leitos macas grosseiras de cipós e jiraus sotopostos a fibras tiradas da entrecasca de certas árvores. Nos quartos de dormir havia uma espêssa camada de fôlhas para impedir a umidade do chão. (idem, p. 978-979)

Muito além de descrever as características da habitação que serviu como refúgio para Eduardo Angelim no momento em que os cabanos sofriam uma sistemática repressão imposta pelas "forças legais", esse fragmento se notabiliza pela perspectiva de reconstituir as utilidades e os usos dos saberes sobre o mundo natural amazônico. Assim, aspectos característicos da respectiva moradia - que na percepção do barão representam a "incivilidade" e a "pobreza" dos rebeldes -, como a utilização de ramas de palmeiras, pedaços de madeiras e cipós, podem ser considerados como símbolos da sabedoria informal, adotada por grande parte das populações amazônicas naquela conjuntura.

Ademais, outro artifício dos rebeldes, relatado em Motins politicos, que pode ser caracterizado como uma das práticas integrantes dos "saberes cabanos" consistia na participação em festas religiosas como pretexto para a realização de reuniões ou pontos de encontro entre os insurgentes. Sobre esse aspecto, a descrição realizada 
por Raiol sobre a Festa de São Tomé, realizada em Belém, se constitui em um fragmento revelador:

$\mathrm{Na}$ estrada de Nazaré, no chamado Largo da Memória, numa casa antiga de Tenreiro Aranha, o crioulo liberto geralmente conhecido pelo nome de Patriota, reunia a plebe e a predispunha para a revolta. No fim da Rua da Pedreira, no ponto chamado Bacuri, também se faziam reuniões de noite, servindo de pretexto a festa de São Tomé, que todos os anos ali solenizavam desde o dia de Natal até o de Reis, com grande concorrência de vadios e libertinos, que lá movidos menos por sentimentos religiosos do que por desejos de assistir aos pagodes noturnos com que glorificavam o santo! [...] E era esta a causa principal que atraía para ali a concorrência dos devotos que tôdas as noites lá iam dançar, comer e beber... E era esta concorrência que tornavam insuspeitas as reuniões dos revoltosos naquelas imediações. (idem, p. 542)

As palavras do barão em relação à Festa de São Tomé realizada em Belém durante a primeira metade do século XIX, além de representarem uma fonte substancial, em razão da "escassez de testemunhos sobre o comportamento e as atitudes das classes subalternas do passado" (Ginzburg, 2006, p. 11), revelam que as populações não alfabetizadas utilizavam-se de uma grande variedade de estratégias e saberes com o desígnio de ludibriar a vigilância imposta pelas elites dominantes provinciais.

A aglomeração de pobres, índios e escravos em uma festividade religiosa, com a suposta pretensão de conspirar contra as elites detentoras do poder e do saber formal na Amazônia, se constitui em um interessante indício de que os pensamentos, ações e crenças de populações não letradas na região, durante o contexto das décadas de 1820 e 1830, adequavam-se a estratégias diversas, envolvendo até mesmo a religiosidade. Assim, a atitude de tentar ludibriar os detentores do poder e do conhecimento letrado, que poderiam não conseguir distinguir se o envolvimento de pobres e escravos nas festas religiosas era motivado pela devoção ou não, acusa a utilização dos "saberes cabanos". Essas "astúcias", elaboradas por pessoas "ignorantes", que geralmente desconheciam as letras, em muitas situações conseguiram iludir as elites apresentadas como ilustradas.

Muito além de ser pensada superficialmente como um processo de subversões político-sociais na Amazônia, a Cabanagem também deve ser refletida como conflito envolvendo saberes formais e informais, em que cada um dos grupos participantes buscava fazer uso do conhecimento que tinha à sua disposição no contexto de lutas. Mesmo várias décadas após o fim do movimento insurrecional, os detentores do poder imperial, entre os quais figurou com destaque no Pará o autor Domingos Antônio Raiol, pareciam ainda estar envolvidos nessas "batalhas", ao almejarem consolidar seus valores e anseios em defesa do conhecimento letrado e do Império.

\section{FECHANDO ALGUNS PONTOS}

Este artigo procurou evidenciar que o foco da elite letrada no Pará e na Amazônia do século XIX era a educação formal, ou as suas "carências" ou "faltas". 
Para essa elite e especialmente nos estudos de Raiol, seu exímio representante, povos iletrados eram sinônimo de "anarquia" e "motins" se deixados à sua própria sorte. Eles assim justificam sua autoridade sobre essa imensa população, atrelando esse poder com a consolidação do domínio regencial e, depois, imperial na região, que ocorreu apenas na segunda metade do século XIX, já no governo da maioridade de Pedro II. Assentados em conceitos como os de civilização, a elite imperial amazônica via os cabanos (que foram derrotados em 1840) como "ignorantes" e analfabetos. Mais do que não saber ler as letras, os cabanos derrotados não conheciam maneiras "letradas" ou "cultas" de conhecer o mundo.

Todavia, apesar dessa carga de preconceitos, compreensíveis dentro de uma cultura erudita da época, notamos também que os letrados conseguiam apreender mesmo que ao revés - alguns saberes cabanos. O que homens como Raiol denominavam de "espertezas" e "artimanhas" dessas populações incultas, hoje podemos ler como conhecimentos e saberes. Esses saberes constituem o que hoje denominamos de uma educação informal. Eles demonstram que, para além de saber ler as letras, os cabanos conheciam meios interessantes e importantes de apreender o mundo que os rodeava, sua natureza, a religião e o circuito católico popular.

Discutir esses saberes cabanos - mesmo que pela leitura arrevesada de Raiol-é recuperar uma história importante por, pelo menos, dois motivos. Primeiramente para percebermos como, historicamente, a escola e sua educação formal desqualificaram (e, infelizmente, muitas vezes, ainda hoje, desqualificam) conhecimentos e saberes de mundo relevantes e fundamentais para o crescimento social e cultural de todos nós. Em segundo plano, porque os saberes cabanos podem nos ajudar a entender o quanto nossa sociedade formal e mesmo nossos conteúdos escolares ainda hoje qualificam e desqualificam conhecimentos de mundo com base em critérios de governo e de poder.

Por fim, a investigação sobre as concepções impressas na obra de um barão amazônico e direcionadas à interação entre analfabetismo e participação no processo de lutas da Cabanagem revela que muito ainda deve ser estudado, na perspectiva de conhecer e dialogar com os saberes "informais" que integravam o cotidiano das populações não letradas no Pará e no Brasil do século XIX. Livros como o de Raiol, escritos sob a luz do poder monárquico, embora caracterizados pela perspectiva de desprestigiar esses conhecimentos, considerados distantes dos ideais de "progresso" e "civilização", acabaram, curiosamente, transformando-se em fontes importantes para a análise e reflexão sobre os comportamentos e experiências das chamadas "turbas", que tanto seu autor procurava evitar.

\section{REFERÊNCIAS}

Andréa, F.J. S. S. Discurso com que o Presidente da Provincia do Para fez a Abertura da $1^{a}$ Sessão da Assemblea Provincial no dia 2 de março de 1838. Belém: Typographia Restaurada de Santos e Santos menor, 1838.

Baena, A. L. M. Ensaio corográfico sobre a provincia do Pará. Brasília: Senado Federal, Conselho Editorial, 2004. 
Benjamin, A. C. Indice ou repertorio geral das leis da Assembléa Legislativa provincial do Gram Pará (1838-1853). Belém: Typographia Commercial de Antonio Joze Rabello Guimarães, 1854.

Bezerra Neto, J. M. As luzes da instrução: o Asylo de Santo Antonio em Belém do Pará (1870-1912). In: Marin, R. A. (Org.). A escrita da história paraense. Belém: NAEA/ UFPA, 1998. p. 185-205.

CANÁRIo, R. Educação de adultos: um campo e uma problemática. Lisboa: ANEFA e EDUCA, 2000.

Carvalho, J. M. A construção da ordem: a elite política imperial. Teatro das sombras: a política imperial. 3. ed. Rio de Janeiro: Civilização Brasileira, 2007.

Castanho, S. E. M. A educação escolar pública e a formação de professores no Império brasileiro. In: Lombardi, J. C.; Nascimento, M. I. M. (Orgs.). Fontes, história e bistoriografia da educação. Campinas: Autores Associados; HISTEDBR: Curitiba, 2004. Chalnoub, S. Cidade febril: cortiços e epidemias na Corte imperial. São Paulo: Companhia das Letras, 1996.

Chiavenato, J. J. Cabanagem: o povo no poder. São Paulo: Brasiliense, 1984.

Coelho, G. M. Linguagem e utopia: figuras do discurso civilizacional pombalino na Amazônia. In: Seminário Landi e o Século XVIII na Amazônia, 2003, Belém. Anais eletrônicos... Belém: UFPA, 2003.

Estratégias civilizacionais: língua e poder na Amazônia pombalina. Anais da Biblioteca e do Arquivo Público do Pará, Belém, v. 5, t. 1, 2006.

Costa, A. L. J. À luz das lamparinas. As escolas noturnas para trabalhadores no município da Corte (1860-1889). 2007. Dissertação (Mestrado) - Programa de Pós-Graduação em Educação, Universidade Estadual do Rio de Janeiro, Rio de Janeiro, 2007.

Cruz, A. Nota sobre a Reforma Pombalina da Instrução Pública. Revista da Faculdade de Letras da Universidade do Porto, Porto: FLUP, n. II, p. 1-64, 1971. Disponível em: <http://ler.letras.up.pt/uploads/ficheiros/3104.pdf>. Acesso em: 3 dez. 2012.

Cruz, E. Nos bastidores da Cabanagem. Belém: Oficina Gráfica da Revista de Veterinária, 1942.

Di Paolo, P. Cabanagem: a revolução popular da Amazônia. 2. ed. Belém: Editora Cejup, 1990.

D’Oliveira, M. Relatorio de 3 de dezembro de 1833. Belém: Typhograhia do Correio, 1833.

Elias, N. O processo civilizador. Tradução de Ruy Jungmann. Rio de Janeiro: Jorge Zahar, 1994.

Frade, I. C. A. S. Uma genealogia dos impressos para o ensino da escrita no Brasil no século XIX. Revista Brasileira de Educação, Rio de Janeiro: ANPEd; Campinas: Autores Associados, v. 15 n. 4, p. 264-281, maio/ago. 2010.

Ginzburg, C. O queijo e os vermes: o cotidiano e as ideias de um moleiro perseguido pela inquisição. Tradução de Maria Betânia Amoroso. São Paulo: Companhia das Letras, 2006. 
Harris, M. Rebellion on the Amazon. The Cabanagem Race, and popular culture in the north of Brazil, 1798-1840. New York: Cambridge, 2010.

Hurley, H. J. A Cabanagem. Belém: Livraria Clássica, 1936.

Maciel, L. S. B.; Neto, A. S. A educação brasileira no período pombalino: uma análise histórica das reformas pombalinas do ensino. Educação e Pesquisa, São Paulo: USP, v. 32, n. 3, p. 465-476, set./dez. 2006. Disponível em: <http://www.scielo.br/pdf/ep/v32n3/ a03v32n3.pdf>. Acesso em: 3 dez. 2012.

Manacorda, M. A. História da educação: da Antiguidade aos nossos dias. Tradução de Gaetano Lo Monaco. 12. ed. São Paulo: Cortez, 2006.

Miranda, J. A. Discurso recitado pelo exm. snr. doutor João Antonio de Miranda, prezidente da provincia do Pará na abertura da Assembléa Legislativa Provincial no dia 15 de agosto de 1840. Pará: Typ. de Santos \& menor, 1840.

PaIva, V. P. Educação popular e educação de adultos: contribuição a história da educação brasileira. São Paulo: Loyola, 1973.

Pinheiro, L. B. S. P. Visões da Cabanagem: uma revolta popular e suas representações na historiografia. Manaus: Valer, 2001.

RaIOL, D. A. Motins politicos ou história dos principais acontecimentos políticos na província do Pará desde o ano de 1821 até 1835. Belém: Universidade Federal do Pará, 1970. (Coleção Amazônica, série José Veríssimo)

Revel, J. Usos da civilidade. In: Chartier, R. (Org.). História da vida privada 3: da Renascença ao século das luzes. Tradução de Hildegard Feist. São Paulo: Companhia das Letras, 2009.

Ricci, M. História amotinada: memórias da cabanagem. Cadernos do CFCH, Belém: Universidade Federal do Pará,v. 12, n. 1-2, p. 13-28, 1993.

. Do sentido aos significados da Cabanagem: percursos historiográficos. Anais do Arquivo Público do Pará, Belém, v. 4, t. I, p. 241-274, 2001.

Romanelli, O. História da educação no Brasil. 30. ed. Petrópolis: Editora Vozes, 2006. Roque, C. Cabanagem: epopeia de um povo. Belém: Imprensa Oficial, 1984.

Salles, V. Memória bibliográfica do Grão-Pará: Cabanagem. Brasília: Micro Edição do Autor, 2005.

Schneider, O.; Neto, A. F.; Alvarenga, J. A. A escolarização e a sua obrigatoriedade: debates na província do Espírito Santo (1870-1880). Educação em Revista, Belo Horizonte: Universidade Federal de Minas Gerais, v. 28, n. 2, p. 175-202, jun. 2012.

Schueler, A. F. M. Crianças e escolas na passagem do Império para a República. Revista Brasileira de História, São Paulo: ANPUH, v. 19, n. 37, set. 1999.

Silva, I. A. C. Corografia paraense ou descripscão física, historica, e politica da provincia do Gram-Pará. Salvador: Typografia do Diario, 1833.

Souza Franco, B. Discurso que recitou o exmo. senhor doutor Bernardo de Souza Franco, presidente da Provincia do Grão-Pará na ocasião da abertura da Assembléia Legislativa Provincial no dia 15 de agosto de 1839. Belém: Typographia Santos \& menor, 1839. 
Thompson, E. P. Os românticos: a Inglaterra na era revolucionária. Rio de Janeiro: Civilização Brasileira, 2002.

Veiga, C. G. A escolarização como projeto de civilização. Revista Brasileira de Educação, Rio de Janeiro: ANPEd; Campinas: Autores Associados, n. 21, p. 90-103, set./dez. 2002.

\section{SOBRE OS AUTORES}

Magda Ricci é doutora em história pela Universidade Estadual de Campinas (UNICAMP). Professora da Universidade Federal do Pará (UFPA). E-mail:magdaricci@ufpa.br

Luciano Demetrius Barbosa lima é professor da rede estadual de ensino do Pará e doutorando em história pela Universidade Federal do Pará (UFPA).

E-mail: dehistoriador@yahoo.com.br

Recebido em julho de 2013

Aprovado em outubro de 2014 